\title{
Assessing the Innovation-finance Nexus for SMEs: Evidence from the Arab Region (MENA)
}

\author{
Abderazak Bakhouche ${ }^{1}$
}

Received: 15 November 2020 / Accepted: 26 March 2021 / Published online: 24 April 2021

(c) The Author(s), under exclusive licence to Springer Science+Business Media, LLC, part of Springer Nature 2021

\begin{abstract}
SMEs in the Arab region are widely viewed as important for their multiple roles, notably in employment creation. Yet, they consistently encounter several constraints such as financing, which impede innovation, growth and internationalisation. This paper examines the external finance-innovation nexus for SMEs operating in five non-oil Arab countries-Egypt, Jordan, Lebanon, Morocco and Tunisia. To achieve this, a probit regression with instrumental variables is applied to firm-level data from the World Bank Enterprise Surveys. The primary findings reveal that the external finance providers are more likely to be reluctant to fund SMEs' innovation; yet, it thrives with finance. The findings accord with the hypothesis that the accessibility to external funds is a mainstay of SMEs' innovation. There is a need to develop policies that support equity and debt capitals for innovative SMEs.
\end{abstract}

Keywords Developing countries - Access to finance $\cdot$ Innovation $\cdot$ SMEs $\cdot$ Probit regression · Middle East and North Africa (MENA) · Egypt · Jordan · Lebanon · Morocco $\cdot$ Tunisia

\section{Introduction}

In developed and developing countries, SMEs have a significant impact on employment, economic growth (Gunjati \& Adake, 2020) and social progress (IMF, 2019). Ever since Schumpeter (1911), the literature has analysed the role of finance in the relationship between innovation, firm growth and overall economic growth (King \& Levine, 1993; Malhotra et al., 2007; Ullah, 2019). As much as innovation is a significant precursor of firms' growth, innovation cannot progress in isolation from the obtainability of sufficient funding (Donbesuur et al., 2020). Even though the credit constraining conditions may not discriminate between innovative and noninnovative

This article is part of the Topical Collection on Industrial Innovation Excellence.

Abderazak Bakhouche

abakhouche@hct.ac.ae

1 Dubai Men's College, Higher Colleges of Technology, Dubai, UAE 
firms (Fernandez, 2017), it is more conspicuous for small- and medium-sized enterprises (SMEs). For this business segment, innovation broadly hinges on the broad participation of the providers of external finance. A strand of studies (Malhotra et al., 2007; Fombang \& Adjasi, 2018; Pérez-de-Lema et al., 2021) unearth consistent evidence that sufficient funding is one of the most critical antecedents for SMEs' propensity to innovate.

The empirical studies focus on the degree to which innovative SMEs are creditconstrained to propose suitable policy interventions. These studies are predicated upon the assertion that aiding SMEs to grow through innovation will yield favourable widespread economic effects in the long run. The literature on the finance-innovation nexus is sizeable; however, there is a broad scope for further inflation due to the economic and social importance of SMEs and the evolving environment where they operate (Archibugi et al., 2013). The confluence of the recent 2007-2009 financial crisis, the role of entrepreneurship in the recent ICTs revolution, and the application of these ICTs in finance has elevated the finance-innovation nexus for SMEs to prominence in the policy and research agenda worldwide (Higon, 2012; Paunov, 2012).

Against this backdrop, SMEs depend on innovation to expand, compete, export and survive (Agénor \& Canuto, 2017; Malhotra et al., 2007; Agénor \& Canuto, 2017). However, their ability to innovate is often limited as they face difficulties in convincing credit markets to provide them with sufficient funding. This view is supported by findings from the literature on financial intermediation, such as studies on bank risk-taking and stability (e.g. Brei et al., 2020), which views that innovative firms are exposed to significant information asymmetries and lack of suitable collateral, making them a potential source of bank fragility (Law et al. 2018). Banks respond by higher loan prices and stringent borrowing requirements. This obstacle is exacerbated in countries where the financial system is less developed and deepened, and options of formal financing are limited (Fowowe, 2017; Wellalage \& Fernandez, 2019).

The MENA region is no exception. In particular, SMEs play an important role in Egypt, Jordan, Lebanon, Morocco and Tunisia. These countries share numerous structural features as they do not depend on oil export revenues for economic growth. The public sector is significant, but SMEs predominate the private sector, especially in its informal segment (IMF, 2019). They are import-oriented even though a growing number of SMEs in Egypt, Morocco and Tunisia are involved in exporting activity (Dornel et al., 2020).

Banks dominate the financial system in the five countries. Their investment decisions prefer lending to the public sector, and accommodating a limited number of large private enterprises (EBRD, 2016). Credit for other establishments, such as SMEs, is limited, which, consequently, poses serious hindrance for their growth, development and internalisation. The SME innovation has reached its potential due to widespread unemployment, low private investment and broad financial inclusion (IMF, 2019). This financing constraint is augmented by the cumbersome regulation and unfavourable administrative procedures, widespread market distortions and skill mismatch due to inadequate human capital (Ayadi \& Sessa, 2017).

Building on the above, although there are numerous studies on the financinginnovation relationship for SMEs worldwide, the impact of access to finance on 
innovation has not been comprehensively addressed in the MENA region. This issue, which is one dimension in the wider firm-financing gap, is likely to remain of high priority for policymakers in the context of recent political and socio-economic transformations that shook the region (EBRD, 2016).

This paper investigates the extent to which SMEs' innovation is impacted by financing constraints in five non-oil-based countries in the MENA region. Innovation activities encompass the introduction of new products, new services, new process and spending on R\&D (Fombang \& Adjasi, 2018).

This paper contributes to the stream of studies on the finance-innovation nexus for SMEs in the MENA region in many main ways.

First, the paper adds further evidence to the literature examining the various constraints preventing SMEs from further growth. The survival and role of SMEs have been a common theme in research and policy around the 2007-2009 financial crisis (Cowling et al., 2012). As a result of this crisis, banks firmly regard SMEs as highly risky due to their less robust information and collateral channels. More recently, COVID-19 pandemic has painfully disrupted the SMEs ecosystem, which necessitated government intervention (Dornel et al., 2020). Thus, the investigation of constraints faced by SMEs is an incessant undertaking due to the evolving feature of the environmental system of influences, which feed into firm-level innovation outcomes. The finance-innovation dimension will continue to occupy a central point in various research agenda and policy in the light on the recent appeals to pursue inclusive growth policies as policy goals rather than focusing on GDP-based policies (IMF, 2019).

Second, although there is abundant literature on the role of innovation by SMEs using data from developing and developed countries, it remains incomplete as each country case offers a different time-varying multi-dimensional context of influences affecting SMEs. Recent studies such as Schneider and Veugelers (2010), Mason and Brown (2013), Mina et al. (2013), Nightingale and Coad (2014), Fowowe (2017), Quartey et al., (2017), Fombang and Adjasi (2018) and Yano and Shiraishi (2020) suggest that innovation is an essential conduit through which SMEs stimulate economic growth, create employment creation and expand to foreign markets. However, next to finance, the same literature considers a set of several firm-specific and fixed effects factors relevant SME innovation behaviour. In this respect, this paper controls for the relationship between several firm-level characteristics and the propensity to innovate such as size, the gender of management and ownership, properties of ownership and the sector of activity. These features may single out innovative firms, so the policy interventions can effectively and efficiently channel funds to eligible firms with these set of features.

Third, the focus of this paper is the finance-innovation nexus by examining the ability of SMEs to obtain external finance and innovate. Available evidence suggests that innovation is fundamental for SME's growth and survival (Coad \& Rao, 2008; Fombang \& Adjasi, 2018; Fowowe, 2017; Mina et al., 2013; Quartey et al., 2017). And that external finance has a significant effect on SMEs' innovation (Rajan \& Zingales, 1998; Wang, 2016). Broadly, SMEs tend to be less favoured by the credit market and find it difficult to obtain finance for innovation (Law et al., 2018; Revest \& Sapio, 2010). Given that the cost of funds increases with information asymmetries, innovative 
firms are often excluded from a "good borrowers" category by financial institutions (Mina et al., 2013; Wellalage \& Fernandez, 2019).

Finally, although there is sizeable number of studies on the relationship between financing and innovation in many developing and developed countries, as studies on MENA region are next to scarce. Some studies on the non-GCC countries in the MENA region (e.g. Ayadi \& Sessa, 2017) reveal that SMEs are unable to further develop due to lack of sufficient formal funding. However, these studies do not focus on the fundamental concern that access to external finance may be a major constraint to SMEs for their innovation activities. This paper bridges this gap by taking the MENA region as a case for analysing the influence of access to finance on SMEs' capacity to innovate.

Generally, the MENA region, especially the five non-GCC countries under study, offers an interesting case for examining the finance-innovation nexus for two main reasons.

In the 1980s-1900s, economic liberalisation reforms supported by Bretton woods institutions have characterised economic policies in these countries. Measures such as privatisation have reduced the size of the public sector and promoted the role of the private sector. One important aspect of these policies is to enable SMEs to play a more significant role in economic growth by developing existing SMEs and easing doing business by lowering cost and obstacles related to entrepreneurship activities. Many SMEs in these countries have benefited from various domestic or multilateral government-backed funding programmes, such as those with the EU institutions (Ayadi \& Sessa, 2017). However, the effects of these interventions and multilateral assistance seem to be limited as many barriers continue to be in place constituting serious hindering to SMEs, especially when attempting to obtain sustainable access to bank finance.

More recently, the MENA region has been disrupted by profound political and socio-economic transformations, with strong ramifications on the broader business environment. The countries under study witnessed substantial changes in governance in response to widespread social unrest and political turbulences, which even created another barrier for SMEs as cost of financing has increased (Belkhir et al., 2017). This social turmoil may be relatively interpreted as an emergence of new post-liberalisation social arrangements aiming at sustainable amelioration of socio-economic conditions, especially employment for the educated youth (EBRS, 2016). As the role of SMEs is substantial in shrinking unemployment, the inability to play such a function may remotely be signalling idle or broken finance-innovation nexus.

Additionally, the investigation of the finance-innovation nexus in the five MENA economies may be of impulsion to policyholders for macroeconomic reasons. The globalised environment has increased these economies' exposure to worldwide competition with other regions to attract foreign direct investments in various sectors. Foreign investments continuously relocate, seeking lower costs and better human and physical capital, in countries where a well-developed ecosystem sub-contractors are already in place. SMEs occupy a strategic position in this system of sub-contraction as they provide for these internationals. The need to construct an environment where SMEs can innovate and transform into disruptors may constitute an influential pull 
factor for foreign investment. Indeed, this aim is achieved by coordinating different policy levels such as the foreign investment policy, the human capital and the financing policy. Thus, availing sufficient funding for SMEs for innovation may stimulate the entry of foreign investment.

Against this background, this paper examines SMEs' access to financing in five countries from the MENA region: Egypt, Jordan, Lebanon, Morocco and Tunisia. The countries have similar characteristics: notably, the economic structure is not dependent on oil export, and the financial system is bank-based with weak equity and debt markets. SMEs are highly active, in both formal and informal sectors. However, innovation seems to be highly credit-constrained.

The paper uses the country-level datasets deployed by the World Bank Enterprises Surveys, which has enabled the recent literature to conduct thorough analyses of the impact of a variety of constraints faced by SMEs on their innovation. This paper aims to reinforce understanding of the importance of finance in SME innovation and the need to enact well-functioning financial markets for long-term inclusive economic growth.

The paper proceeds as follows. "The Literature Review" presents selected literature finance-innovation nexus relevant to the MENA region. "Methodology: Regression Specification" outlines the methodology employed. "Data and Sample Description" describes the dataset. "Empirical Strategy" presents the estimation strategy. "Results and Discussion" presents and discusses the results. "Conclusion" draws policy recommendation and conclusion.

\section{The Literature Review}

The literature has ascertained the importance of innovation as a critical driver for the growth of the firm and the economy (Yano \& Shiraishi, 2020). The realisation that SMEs play an essential role in the country's employment generation, value added and the innovation system has led to propose several channels to help SMEs innovate and propagate. Earlier studies focus on the advantages that SMEs have compared to larger firms in terms of the managerial and organisational decisions (Rothwell \& Gardiner, 1989) and the ability to adapt to changes in the institutional environment (Scherer, 1988; Link and Bozeman, 1991). Studies emerging in the 1990 and 2000s focus on the importance of financial systems to foster the growth of firms (Demirguc-Kunt \& Maksimovic, 1998; Beck et al., 2006; Butler \& Cornaggia 2011; Girma et al., 2008; Beck et al., 2008a, b; Law et al., 2018).

However, it has been documented that SMEs are highly credit-constrained. Berger and Udell, (1998) suggest that external financing for SMEs is extremely important, especially for younger firms. Denis (2004) finds that external financing is difficult for SMEs for two reasons: information asymmetries and the moral hazard problems (Akerlof, 1970; Stiglitz, 2000). Information asymmetry will limit a firm's external credit accessibility and restrain its financing and investment decisions (Tang, 2009).

There are two reasons which have motivated recent studies on SMEs' financeinnovation nexus. First, bank financing has the most significant effect on firm-level innovation (Wellalage \& Fernandez, 2019). However, SMEs continue to suffer from 
financing frictions despite their significant contribution to the recovery from economic slowdowns (Ayyagari et al., 2017). Second, the availability of a large scale of more homogenous survey-based datasets for most countries, such as those prepared by the World Bank Entreprise Surveys (WBES), has enabled gaining further firm-level evidence-based insights on the factors influence state of SME's innovativeness. The WBES offer firms' responses on various constraints to doing business and accessibility to credit markets by SMEs (Chava et al., 2013; Fombang \& Adjasi, 2018; Xin et al., 2017).

More recent studies stress on the importance of availing sufficient funding for SME's innovation. Based on this background, the literature empirically documents the channels through which inadequate access to finance may act as a deterrent to innovation (Beck et al., 2008b; Law et al., 2018; Wellalage \& Fernandez, 2019). The most salient finding by research on the finance-innovation is that smaller firms are substantially dependent on external financing, but they face more obstacles to obtaining finance than larger firms (Beck et al., 2002; Cornaggia et al., 2015).

By large, the literature on the external finance-innovation nexus is broadened on Schumpeter's seminal contributions (1911, 1934). Schumpeter prepones that economic growth is driven by innovation and that innovation is contingent on the availability of finance channelled through the efficient functioning of the credit markets. The availability of finance, among other factors, augments the capacity to invest in human and technological capitals and therefore increases the propensity to innovate. Schumpeter alleges that innovation disrupts markets by causing a substitution effect through replacement of existing products with new products. As this process of replacement requires capital, the intervention of financial intermediation throughout all stages, from conception to stimulating demand for the innovation outcome, is indispensable. As such, smooth access to finance may be considered as a significant driver of innovation, since it enables long-term growth and survival (Ayyagari et al., 2011; Fernandez, 2017).

Gonzales et al. (2014), Agénor and Canuto (2017) and Law et al. (2018) reveal that credit markets do not favour innovation activities by SMEs because they are associated with lack of collateral, significant informational opaqueness and higher monitoring costs. This makes their valuation a difficult undertaking (Nofsinger \& Wang, 2011), leading them to be excluded from a creditworthy category by financial institutions (Mina et al., 2013; Ayyagari et al., 2014). Banks may not consider the intangible capital produced by a research process not as a collateral of value (Lee et al., 2015; Mina et al., 2013).

A strand in the literature on developing countries relates the barriers faced by innovative SMEs when accessing external finance to the less development and less deepening of the respective credit market. For instance, Chava et al. (2013) and Xin et al., (2017) find that lower competition in the credit market aggravates the finance-innovation link for younger firms. Fombang and Adjassi (2018) find that the availability of various lending modes such as trade credit, assets finance and overdraft, enhances for SMEs eases access to finance for innovation, as it avoids seeking finance from other more expensive sources. Wellalage and Fernandez (2019) reveal that SMEs resort to trade credit in the informal market as a source in firm-level innovation when they face difficulties with bank financing. Yano and Shiraishi (2020) 
show that well-defined property right and contracts are important factors influencing the effectiveness of funding on innovative firms.

Therefore, the Schumpeterian argument that finance has a positive effect on innovation. However, although previous studies show how financial constraints hinder innovation activity projects, the empirical literature on the relationship between financial constraints and innovation is not entirely conclusive (Canepa \& Stoneman, 2007; Lee et al., 2015; Wellalage \& Fernandez, 2019). Accessibility to financing for small and medium enterprises (SMEs) is not uniformly available in all economies. Berger and Udell (2006) find that the type of finance options available to SMEs may vary according to the phase of their respective lifecycle.

\section{Methodology: Regression Specification}

To estimate the effects of access to external finance on SME innovation, we employ an empirical model, which relates forms of innovation to variables controlling for the degree of access to finance incidence and severity as indicators for financing constraint, and several firm-level specific characteristics and country dummies. Our adoption of the variables proxying firm's characteristics depends on (i) the extent of emphasis in the literature, (ii) the availability of sufficient data and (iii) the low correlation among these variables. The set of firm heterogeneities employed in this study covers firm' size, gender, business sector, exporting status, use of technology, international recognition, business sector and country of activity (e.g. Lee et al., 2015; Love et al., 2016).

The model is presented in Eq. (1) as follows:

$$
I_{\mathrm{i}, \mathrm{c}}=\alpha+\beta F I N_{\mathrm{i}}+\gamma X_{\mathrm{i}}+\varepsilon_{\mathrm{i}}
$$

where the subscripts $i$ indexes firm and c denotes country,

$\alpha$ is the constant representing the firm-level fixed effects. It embeds the general state of innovation independent of other factors. It can be seen as a gauge of how innovation is enshrined in firm's business model.

$\varepsilon$ is an error term and assumed to be iid $N\left(0, \sigma_{\mu}\right)$.

First, $I$ is a binary variable taking the value of 1 if the firm $i$ has an innovation output or made an innovation effort and 0 otherwise. Based on Czarnitzki (2006), Van Beveren and Vandenbussche (2010), Costello and Prohaska (2013), Lee et al. (2015), Baskaran and Mehta (2016) and Denicoló and Zanchettin (2016), an innovation effort is related to whether the firm spent on formal in-house or out-sourced research and development activities (R\&D) in the previous 12 months; innovative output refers to whether a firm introduced a new or significantly improved product, service or process in the previous 3 years.

Second, FIN represents our financing constraints variables measured at two levels: severity and incidence (Lee et al., 2015). We concentrate on financing constraints to all types of debt (all maturities, trade credit, asset finance and overdraft). 
- Severity of access to finance $(O B S F I N)$ is captured as 1 if the firm identifies "access to finance" as a "major" or "very severe" obstacle to its innovative activities, and 0 otherwise.

- Incidence of credit (CREDIT) is a dummy taking the value of 1 if the firm obtained a line of credit or loan from a financial institution at the time of the interview or applied for these in the previous 12 months, and 0 otherwise.

Third, $X$ is a set of independent variables, which control for the following:

- Size of the firm is measured by the number of employees and captured by three dummies: small, medium and large. Small is for enterprise employing between 5 and 19 persons; medium is for firms employing between 20 and 99, and large is for firms employing 100 persons and more. Age is ignored because of high correlation with size. We retain two size dummies: SIZE_SMALL and SIZE_LAERGE.

- Foreign ownership (FOREIGN) is a dummy taking the value of 1 if the firm is partly or fully owned by foreign capital, and 0 otherwise

- Export orientation (EXPORT) is captured as " 1 " if the firm is involved in the export market or " 0 " otherwise. A firm is considered an export if at least $10 \%$ of its annual sales is derived from direct exports.

- Web use is (WEB) measures whether the firm uses own website for businessrelated activities such as sale and product promotion.

- International recognition (INTRECOGN) is a measure of quality taking the value of 1 if the establishment has internationally recognised certification of product, service or process, and 0 otherwise.

- Gender is a dummy, GENDER_FEMALE, proxying for the involvement of women, in both in management of ownership of the establishment.

- Sector refers to the sector classification of the firm (there are two primary classifications: manufacturing and services). MANUFACTURING is retained as a dummy variable for companies in the manufacturing sector.

- Country refers to the country where the firm originates and operates. A total of four dummies capture this location dimension.

Based on the proposition by Schumpeter $(1911,1934)$, and in congruence with the studies on the firm-level finance-innovation link (e.g. O'Sullivan, 2005; Ayyagari et al., 2011; Fombang \& Adjasi, 2018; King \& Levine, 1993), the specification in Eq. (1) proposes a positive relationship between access to finance and innovation. Thus, we hypothesise that firms with innovation activities tend to rely on external finance.

If an establishment rates the obstacles it faces to obtain external finance as major or severe, or if it had not applied for external finance in the preceding 12 months, as a signal of high likelihood or near certitude of loan rejection, then this should suppress innovation activities in qualitative and quantitative terms. Hence, we test whether there is a relationship between innovation and the degree to which access to finance is difficult.

Regarding the link between innovation and the set of firms' heterogeneities, hypotheses are formulated based on the literature. First, larger establishments are more likely to engage in innovative activities (Fombang \& Adjasi, 2018). Second, 
firms with more females in management and/or ownership may be better placed to be active in innovation (Carter \& Rosa, 1998; Wellalage \& Fernandez, 2019). Third, the adoption of technology in business operations and the gain of international recognition may signal that the establishment is ready to engage in spreading innovation. International recognition may also indicate that the people in the establishment are highly educated and experienced. Fourth, foreign ownership is expected to positively impact innovation due to the spillover of know-how effects. Fourth, the export status controls for the level of export orientation and internationalisation of the establishment, which many studies have found significant for innovation (Ayyagari et al., 2011). Fifth, the sector of activity may be linked to firm innovation as sectors reflect structural differences in the balance sheet and income statements (Cantwell \& Zhang, 2011). Finally, the country of activity may influence innovation as it reflects effects of many country-level factors (Fombang \& Adjasi, 2018).

\section{Data and Sample Description}

The recent literature on SMEs has shifted towards use of survey datasets released by the World Bank Entreprise Survey (WBES), as they present direct measures of variables such as innovation and access to finance, among other dimensions of SMEs.

Thus, our data are extracted from the Enterprise Surveys, undertaken by the World Bank in 2013-2014, and released in 2017 (www.worldbank.org). It is considered the latest dataset at time of preparing this study. The surveys cover 12 topics measured by more than 100 indicators, on more than 139,000 SMEs located in 139 countries. Our sample comprises 4396 SMEs from five MENA countries: Egypt, Jordan, Lebanon, Morocco and Tunisia.

The survey is conducted using a face-to-face interview with firms' managers and owners. The sample is sub-stratified based on firm size, location, business sector, the gender of managers and owners, the exporting status and ownership (foreign vs domestic). Firms are categorised as small for employees between 5 and 19, medium for between 20 and 99 and large for 100 or more employees. Surveyed firms operate in the non-agricultural formal private economy, including the entire manufacturing sector, the services sector and the transportation and construction sectors. A firm with $10 \%$ annual sales derived from exports is regarded as an exporting firm. Finally, a firm is considered "foreign" if foreigners hold $10 \%$ of its capital.

Other questions relate to how SMEs finance their fixed assets and working capital needs. Finance sources include internal funds or retained earnings, loans from government and private banks, loans from non-banks microfinance institutions, credit cooperatives, credit unions, or finance companies, trade credits and receivables advances and other moneylenders, friends and relatives. The following section will discuss a selection of variables.

Table 1 presents frequency estimates on innovative effort and innovative output and innovative inputs for by innovation types across the five countries under study. Estimates are stratified as per involvement in innovation, and as per the type of activity of innovation. Table 1 presents a striking finding: only $40 \%$ of the sample 
Table 1 Distribution of innovative vs non-innovative per country

\begin{tabular}{|c|c|c|c|c|c|c|c|}
\hline \multirow[t]{2}{*}{ Country } & \multirow[t]{2}{*}{ Total firms } & \multicolumn{5}{|c|}{ No. Innovating firms } & \multirow{2}{*}{$\begin{array}{l}\text { Non- } \\
\text { innovators }\end{array}$} \\
\hline & & Process & Product & Service & $\begin{array}{l}\text { Spending } \\
\text { on } R \& D\end{array}$ & Total & \\
\hline Egypt & $2555(58.1)$ & $567(22.2)$ & $783(30.6)$ & $517(20.2)$ & $164(6.4)$ & 808 (31.6) & $1747(68.4)$ \\
\hline Jordan & $427(9.7)$ & $136(31.9)$ & $158(37)$ & $110(25.8)$ & $60(14.1)$ & $166(38.9)$ & $261(61.1)$ \\
\hline Lebanon & $487(11.1)$ & $225(46.2)$ & $289(59.3)$ & $220(45.2)$ & 87 (17.9) & $300(61.6)$ & $187(38.4)$ \\
\hline Morocco & $349(7.9)$ & $154(44.1)$ & $175(50.1)$ & $108(30.9)$ & $63(18.1)$ & $182(52.1)$ & $167(47.9)$ \\
\hline Tunisia & $578(13.1)$ & $222(38.4)$ & $262(45.3)$ & $158(27.3)$ & $118(20.4)$ & 281 (48.6) & $297(51.4)$ \\
\hline Total & $4396(100.0)$ & 1304 (29.7) & 1667 (37.9) & $1113(25.3)$ & $492(11.2)$ & $1737(39.5)$ & $2659(60.5)$ \\
\hline
\end{tabular}

Source: Enterprise Survey, weights applied by the authors

are involved in some form of innovation, and only a tenth of these spend on R\&D. This result confirms the non-prevalence character of innovation for SMEs in the five countries under study.

Innovating firms may be involved in more than one form of innovation: product (37.9\%), service (25.3\%) and process (29.7\%). Firms in Lebanon and Morocco are the most innovative, while firms in Egypt and Jordan are the least innovative. Only $6.4 \%$ of firms in Egypt spend on R\&D, against a range of 14-20\% in other countries.

The estimates from Table 1 conform to the hypothesis that innovation level is not prevalent in the MENA region, especially if it is measured by a stricter measure of "R\&D expenditure", reflecting the presence of structural challenges and barriers.

Table 2 shows sample frequency characteristics for variables proxying access to finance. For the whole sample, 30.9\% of firms had applied to obtain finance and reported facing obstacles. A total of $69.2 \%$ of the sample did not report facing financing obstacles, and this may be due to have sought external finance. This result is also reported in the literature (EBRD, 2016). Table 2 shows that $30.9 \%$ of the sample had credit in their balance sheet; $78.3 \%$ of the sample had savings accounts, with percentages higher in Tunisia, Lebanon, and Morocco.

Table 2 Frequency distribution for access to finance characteristics per country

\begin{tabular}{llllll}
\hline Country & $\begin{array}{l}\text { Have savings } \\
\text { account }\end{array}$ & Have credit & $\begin{array}{l}\text { Firms reported } \\
\text { facing financing } \\
\text { obstacles }\end{array}$ & $\begin{array}{l}\text { Firms reported not } \\
\text { facing financing } \\
\text { obstacles }\end{array}$ & Total \\
\hline Egypt & $1715(67.1)$ & $377(14.8)$ & $781(30.6)$ & $1774(69.4)$ & $2555(58.1)$ \\
Jordan & $364(85.2)$ & $122(28.6)$ & $157(36.8)$ & $270(63.2)$ & $427(9.7)$ \\
Lebanon & $460(94.5)$ & $305(62.6)$ & $190(39.0)$ & $297(61.0)$ & $487(11.1)$ \\
Morocco & $342(98)$ & $190(54.4)$ & $101(28.9)$ & $248(71.1)$ & $349(7.9)$ \\
Tunisia & $560(96.9)$ & $363(62.8)$ & $126(21.8)$ & $452(78.2)$ & $578(13.1)$ \\
Total & $3441(78.3)$ & $1357(30.9)$ & $1355(30.8)$ & $3041(69.2)$ & $4396(100.0)$ \\
\hline
\end{tabular}

Source: Enterprise Survey, weights between parentheses in percentage calculated by the authors 
Accordingly, Table 2 shows that firms licensed in Tunisia (62.8\%), Lebanon $(62.6 \%)$ and Morocco $(54.4 \%)$ have credit in their balance sheet, while this ratio is small for Egypt (14.8\%) and Jordan (28.6\%). This implies that firms in Tunisia, Lebanon and Morocco tend to rely on formal external finance for their operation, while firms in Egypt and Jordan may rely on other financing sources such as informal finance. Table 2 shows SMEs operating in Lebanon, Jordan and Egypt reported difficulties in obtaining finance. Firms in Tunisia, and to some extent, Morocco, are exhibiting lending-friendly environment.

\section{Empirical Strategy}

Studies (e.g. Wellalage \& Fernandez, 2019) which employ survey data to analyse the finance-innovation link recognise the sensitivity of results to two interrelated problems: multicollinearity of predictors and especially endogeneity of innovation and external finance.

First, firm heterogeneities such as size, age and other characteristics may have simultaneous effects on innovation and external finance creating multicollinearity problems, which may involve possible bi-directional causality between finance and innovation (Correa et al., 2010; Morris, 2018). In this paper, although there is a possibility of causality running from innovation to finance, we adopt the Schumpeterianbased traditional view, which may suggest that causality runs from access to finance to firm-level innovation.

Second, the sample selection biases engender the problem of endogeneity of innovation and external finance, as independent variable correlates with the noise term (Higon \& Driffield, 2011). To control for the endogeneity of financing constraints and innovation, we consider an instrumental variable (IV) estimator (Fombang \& Adjasi, 2018; Wellalage \& Fernandez, 2019). Given that there is a lack of rigid approaches in identifying suitable instruments (Fombang \& Adjasi, 2018; Fua et al., 2018; Morris, 2018; Wellalage \& Fernandez, 2019), we select a vector of instruments which capture constraints faced by the establishments which are deeprooted in the business environment and brought about by the prevailing system of political and legal institutions. The selection of this set of variables accords with the hypothesis that access to external finance is more sensitive to the business environment (Morris, 2018). However, innovation may also be stimulated by environment characterised by better infrastructure, more skilled labour and encouraging market regulation (World Economic Forum 2018).

Equation (1) specifies whether SMEs' innovation in the MENA region is influenced by the degree of access to finance. Given that the variables proxying innovation and external finance are binary, we estimate several probit regression models, in congruence with the recent studies on whether the SMEs face barriers to obtaining external funds (Fua et al., 2018; Lee et al., 2015; Wang, 2016). The coefficient on the measure of finance constraint captures the sensitivity of innovation activities to the degree of financing constraints. 
Therefore, our modelling takes the form of cross-sectional probit regressions with instrumental variables where the principal predictor variable is a measure of the degree of access to bank financing. A set of firm-level variables are encompassed in the specification in (1) as controls helping to confine the effect of finance on innovation.

\section{Results and Discussion}

Equation (1) is estimated using IV probit regression to investigate the relationship between innovation by SMEs and the degree of financing constraints.

Table 3 presents the IV probit estimation results for the relationship between innovation activities and variables capturing access to finance and other firmspecific and fixed effects control variables, as specified in Eq. (1). We model the relationships between innovation and external finance by IV probit model to avoid obtaining estimates influenced by endogeneity.

Table 3 is organised into two panels. The regressions in panel 1 retain the "severity of the access to finance" obstacle as a variable controlling for access to finance, while in panel 2, the variable measuring whether the firm had credit is held to control for access to finance.

The results in panel 1 from Table 3 conform to our hypothesis that the degree to which SMEs face obstacles in obtaining external credit has a significant impact on their innovation activities. The sign corresponding to the OBSFIN variable is positive and statistically significant in all estimations, implying that innovating firms are more likely to encounter obstacles when seeking external finance. Additionally, the results in panel 2 from Table 3 suggest a relationship between finance and innovation with a positive and significant sign on the variable proxying incidence of credit, CREDIT. This finding implies that innovating firms tend to accommodate external finance in their capital structure.

These findings strengthen our assertions on the importance of the finance-innovation nexus for SMEs. Innovating firms tend to stimulate demand for external funding, but they find it challenging to obtain it. Our findings are harmonised with the findings by Mazzucato (2013), Lee et al. (2015) and Wellalage and Fernandez (2019), providing further evidence that supports analysis by Schumpeter (1934) that finance, and overall financial development, is a principal condition for innovation.

The weak relationship between innovation and access to finance may reflect structural weaknesses in the financial system. Lee et al. (2015) find that innovating firms are likely to face difficulties to obtain finance than non-innovating firms in a system where banks are the main source of finance because banks may use credit rationing (Freel, 2007). Allocating more credit to SMEs for innovation activities may be associated with higher credit risk with implications of financial soundness for banks. Decisions of credit allocation by financial intermediaries are influenced by factors related to transaction costs, monitoring costs, information asymmetries and sufficient collateral (Allen \& Santomero, 1998). Besides, the absence of a formal well-established infrastructure for alternative channels such as venture capital may have accentuated the broken link between finance and innovation. 


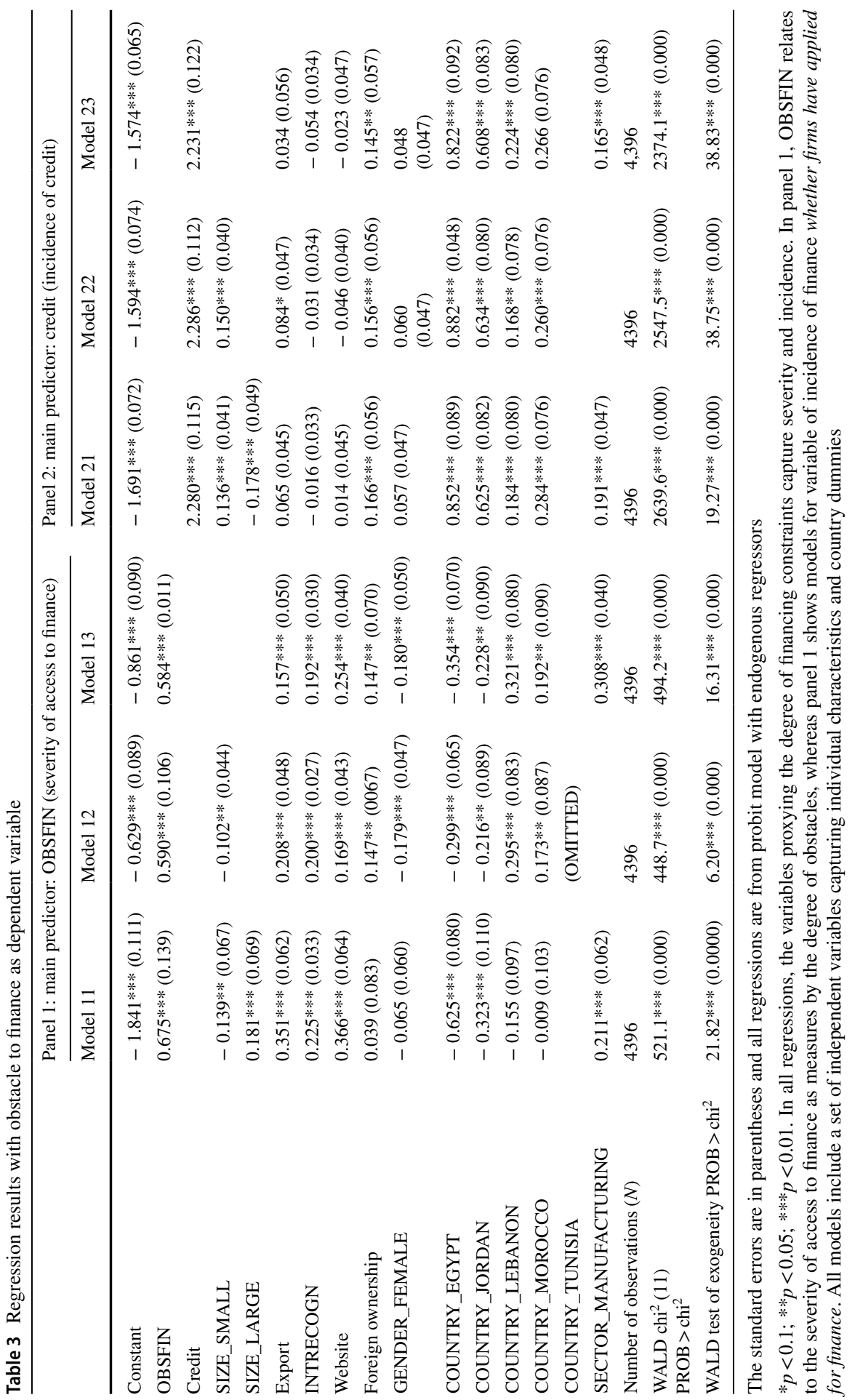


However, Hellmann et al. (2008) advocate establishing relationships between borrowers and intermediaries to reduce transaction costs and lessen information asymmetries. This recommendation is supported by Puri et al. (2011) who find a negative relationship between credit relationships and default risk. Developing bank-customer relationship as a solution, arguing that clients forging expansive relationships with their lending institutions will face lower collateral requirements and enjoy more credit facilities. Borrowers who enjoy longer relationships with their banks will enjoy lower interest rates on credit.

To further reveal the importance of selected SMEs' characteristics on their innovation, Table 3 reports results on the impact of the firm-level variables and fixed effects variables on innovation.

First, the results in panel 1 in Table 3 where the "severity of access to credit, OBSFIN" is retained as the independent variable, the dummy variable, SIZE_ $S M A L L$, carries negative and significant coefficient whereas the dummy variable SIZE_LARGE, has a positive and significant coefficient. We find that larger SMEs are more likely to be engaged in innovative activities than smaller SMEs. This result is consistent with the hypothesis that a firm size has a positive relationship with SMEs' propensity to innovate (Gorodnichenko \& Schnitzer, 2013). Larger SMEs are more likely to make gains from economies of scale, which results in a stronger orientation toward innovativeness (Wellalage \& Fernandez, 2019).

These findings may imply that smaller enterprises are more likely to face obstacles in obtaining finance, making them less innovation-driven than larger establishments.

On the other hand, the results of regressions reported in panel 2 in Table 3 where the "incidence of credit, CREDIT" is the primary predictor variable, yield negative coefficient on the SIZE_SMALL, dummy variables, and positive coefficient on the SIZE_LARGE, dependent variable. These results suggest that, when smaller enterprises, especially entrepreneurial start-ups, have obtained external credit, they tend to be more innovating than larger enterprises. Therefore, our finding conforms to the evidence that smaller firms are more likely to rely on bank loans to fund innovation than larger firms.

The results in both panels in Table 3 show a persistent pattern that harmonise with the hypothesis stressing the link between innovation and technology as that innovation is strengthened by enterprises that adopt technology for their various operations. The adoption of technology proxied by web use (WEB) is found to increase the likelihood of a firm innovating.

The results confirm that innovation is associated with enterprises whose outcomes are certified by international bodies, and which are participating in export activities. The international recognition of products (INTRECOGN) and export orientation (EXPORT) are positively related to innovation. These results may point to the.

This finding is particularly vital as it suggests that for firms to reinforce their export orientation, they need to obtain international certifications, which are significantly linked to innovation. Our results propose a tri-variate framework linking innovation, international certification and expansion in foreign markets. 
SMEs are compelled to depend on innovative outcomes to expand overseas (Corsi \& Prencipe, 2018).

The findings associated with the use of technology (WEB), international certification (INTERCOGN) and export orientation (EXPORT) may collectively reflect a superior quality of the human capital in the firm, as the adoption and implementation of technologies require qualified, skilled and more experienced management and labour in the industry. Several studies (e.g. Capozza \& Divella, 2019; McGuirk et al., 2015; Sarto et al., 2019) find positive relationships between experience as a component of the human capital and the decision to innovate.

Furthermore, the coefficient on the variable FOREIGN proxying direct control of foreign capital of the firm suggests has a positive on firm-level innovation. Several studies show that firms with foreign capital tend to undertake more innovation activities than firms owned by domestic capital (Guadalupe et al., 2012; Wellalage \& Fernandez, 2019). Foreign capital participation improves firm innovation because they channel many spillover innovativeness effects from home countries to domestic markets. Guadalupe et al. (2012) associate foreign capital with the adoption of superior transferred technologies and innovative methods to compete in domestic markets through simultaneous investment in advanced fixed assets, human capital, and new methods to organise production.

Another important finding in Table 3 indicates that innovation is not gender-neutral. There is no evidence to suggest that the presence of females in management and ownership would enhance the firm innovative behaviour, although the coefficient is only insignificant at the 5\% level. The sign and significance of the variable proxying female gender imply that innovation rises when men are the majority. This result is in contrast to findings by several studies such as Sastre (2016) and Palalic et al. (2017) who confirm the positive effects of gender diversity on innovation, maybe because of their women-specific traits (Langan-Fox \& Roth, 1995).

Several studies present explanations for why innovation prosper with men than women for SMEs (Nahlinderm, 2010). Wellalage and Fernandez (2019) note the hypothesis that women are more risk-averse than men, which would be detrimental to innovation because it is inherently a risky activity Alsos et al. (2013) argue that women are marginalised and therefore may show scarcity in motivations, data and instruments to be considered innovative agents. Additionally, we may assert that men and women differ in how to approach innovation due to their distinctive natural differences as explained by the internal and external Locus of control framework (LOC) presented by Rotter (1966). Individuals overwhelmed by internal LOC accredit ability to control events and intend actions based on self-incentives, motivations and emotions. Conversely, Individuals who are dominated by external LOC point at external factors, which have no control of their outcomes, and therefore are driven by more social demand (Graffeo \& Silvestri 2006). Hisrich (1992) and (Khan et al., (2014) indicate that internality of LOC is associated with entrepreneurial orientation. As such, women may conduct innovation that intends to achieve social ends rather than seek higher "personal" economic returns, which may not stimulate interest from loan providers. Given that risk and uncertainty are inherent in innovation, men might view this risk as challenging-inducing and therefore worth taking to confirm skills, capabilities, and overall position in the society. 
Furthermore, the results in Table 3 reveal that the sector of activity has a discriminating effect on innovation. Firms in manufacturing tend to put more innovation plans in place, likely through undertaking product and process innovation in addition to spending on $\mathrm{R} \& \mathrm{D}$, than firms operating in the services sector. These results capture substantial differences in strategies, structures, business models, cost and the quality of the human capital (Donbesuur et al., 2020).

Finally, the results related to country dummies as a proxy for the environmental framework where SMEs operate show that SMEs are more likely to innovate if they are located in Tunisia, Morocco and Lebanon than in Egypt and Jordan.

These results may indicate that innovative firms in the five countries face varying unfavourable environmental complexes, as in other emerging and developing countries (Ayyagari et al., 2011; Wu et al., 2014). Djankov et al., (2007) raise the role of heavy regulation in some industries as disincentives for innovation; Geretto and Pauluzzo (2008) find that significant political and contractual weight of state-owned enterprises constitutes a serious obstacle for SMEs to access the bank loans market; Anokhin and Schulze (2009) and D'Este et al. (2012) mention the bureaucratic barriers to get licenses, permits and certifications, which can restrict SME innovation.

\section{Conclusion}

In many developing and emerging economies, SMEs may face an environment delineated by inadequate legal institutions, widespread information asymmetries and burdensome administrative compliances (Donbesuur et al., 2020). Such institutional framework may serve as a barrier to SMEs' access to finance and hence a propeller to their innovation (IMF, 2019).

A few studies confirm this portrayal. For instance, La Porta et al., (1997), Levine (1998) and Yano and Shiraishi (2020) find that the degree of access to finance characterises the quality of the institutional framework such as the system of legal and political institutions and degree of development of credit market. The findings by same literature imply that the problem of access to finance by innovative SMEs is more pronounced in developing countries, where financial intermediation is less developed. Innovation by SMEs is often undermined by several factors, including inadequate finance, lack of managerial skills, equipment and technology, poor access to capital markets, among others (Garcia-Perez-de-Lema et al., 2021).

This paper contributes to the literature on the finance-innovation relationship by empirically assessing the degree to which access to external finance influences on the innovation of SMEs in five nonoil-based MENA countries. Our results validate the traditional view that access to finance paralleled with several firm's heterogeneities is a mainstay for SMEs' innovation.

Our findings suggest a need for significant policy review and intervention to enhance SME's innovation, which will solidify the degree of competitiveness in foreign markets.

First, SMEs are disadvantaged by bank lending, such as higher loan prices and exhausting collateral requirements. Policymakers should form an adequate and 
comprehensive framework to stimulate flow of equity and debt capitals from different sources to innovative SMEs at more favourable cost and collateral requirements.

Second, the promotion of innovation through the accessibility to of finance will help expose firms in international markets, which increases the demand for domestic goods and services. Therefore, a policy that aims to make a lien between financing and innovation-induced international certification would be fundamental to support SMEs' innovation. This is in parallel, with encouraging presence of foreign capital in the domestic SMEs ecosystem. The policy should enhance the attraction of foreign capital to the SMEs' sector and increase their innovation capability, hence propensity to form export.

Third, the MENA countries should develop a policy to channel more funds to $\mathrm{R} \& \mathrm{D}$ activities, as the current levels of $\mathrm{R} \& \mathrm{D}$ spending ratios are minimal compared to other countries in Asia and Latin America. Specifically, Omar (2019) finds that a $10 \%$ increase in R\&D expenditure is associated with a GDP growth rate of $4 \%$ in the MENA region. The importance of innovation and education on fostering economic growth is leveraged by investment in human capital from an early age. Furthermore, an intervention is urged to invest in R\&D and innovation sector (Hall, 2002), and effectuate innovation within university and research laboratories, and convert these centres of knowledge into wealth-creating entities.

This study has one primary limitation. First, the survey data is cross-sectional information collected by the World Bank Enterprises Surveys (WBES) by instrument of interviews of SMEs owners and/or managers. The interviews took place in 2014 and the related information realised in 2017. The input by these individual may reflect perceptions rather than actual facts, and because of the cross-sectional character of data, the results may capture conditions in specific times, rather than longitudinal conditions which may capture changes over time and reduces endogeneity. Therefore, the employment of other datasets availed by other organisations may enforce the robustness of the results presented here. Other databases may also avail more robust variables which WBES does not capture.

Further research is essential in four main areas. First, future research should consider augmenting the empirical results presented in this paper to seek evidence from broader dataset covering more countries from the MENA region in the context of the recent economic, epidemic and political developments. Second, in congruence with the recent trends in the literature, further research could explore the impact of institutional and financial system's environment, such as competition, on the firmlevel access to finance-innovation nexus, to guide policy towards design and implementation of appropriate policies. Third, given of the significance of the informal sector' size in the MENA region, it may seem a useful contribution to understand the extent to which SMEs resort to informal financing sources to fund innovation, and the implications on their growth. Fourth, due to the neutrality of gender diversity on firm innovativeness, it may seem of notable value to explore how the locus of control (LOC) may impact men and women in forming SMEs and engaging in innovation. Empowering women has a significant positive effect on growth. 


\section{References}

Agénor, P.-R., \& Canuto, O. (2017). Access to finance, product innovation and middle-income traps. Research in Economics, 71, 337-355.

Akerlof, G. A. (1970). The market for "lemons": quality uncertainty and the market mechanism. Quarterly Journal of Economics, 84(3), 488-500.

Allen, F., \& Santomero, A. (1998). The theory of financial intermediation. Journal of Banking and Finance, 21, 1461-1485.

Alsos, G. A., Ljunggren, A., \& Hytti, U. (2013). Gender and innovation: state of the art and a research agenda. International Journal of gender and Entrepreneurship, 5(3), 236-256.

Anokhin, S., \& Schulze, W. S. (2009). Entrepreneurship, innovation, and corruption. Journal of Business Venturing, 24(5), 465-476.

Archibugi, D., Filippetti, M., \& Frenz, M. (2013). The impact of the economic crisis on innovation: evidence from Europe. Technological Forecasting and Social Change, 80(7), 1247-1260.

Ayadi, R., \& Sessa, E. (2017). Micro, small and medium sized entreprises development in Egypt, Jordan, Morocco and Tunisia: structure, obstacles and policies. (p. 3). EMNES Studies.

Ayyagari, M., Demirguc-Kunt, A., \& Maksimovic, V. (2011). Firm innovation in emerging markets: the role of finance, governance, and competition. Journal of Financial and Quantitative Analysis, 46(6), 1545-1580.

Ayyagari, M., Demirguc-Kunt, A., \& Maksimovic, V. (2014). Who creates jobs in developing countries?. Small Business Economics, 43(1), 75-99.

Ayyagari, M., Demirguc-Kunt, A., \& Maksimovic, V. (2017). SME finance. Policy Research Working Paper, 8241 .

Baskaran, S., \& Mehta, K. (2016). What is innovation anyway? Youth perspectives from resourceconstrained environments. Technovation, 52-53, 4-17.

Beck, T., Demirguc-Kunt, A., \& Maksimovic, V. (2002). Financing Patterns around the World: The Role of Institution. Policy Research Working Paper; No. 2905. World Bank, Wanshington, DC. World Bank. https://openknowledge.worldbank.org/handle/10986/19214 License: CC BY 3.0 IGO.

Beck, T., Demirgüç-Kunt, A., \& Maksimovic, V. (2008a). Financing patterns around the world: Are small firms different. Journal of Financial Economics, 89(3), 467-487.

Beck, T., Demirgüç-Kunt, A., Laeven, L., \& Maksimovic, V. (2006). The determinants of financing obstacles. Journal of International Money and Finance, 25(6), 932-952.

Beck, T., Demirguc-Kunt, A. S. L. I., Laeven, L., \& Levine, R. (2008b). Finance, firm size, and growth. Journal of Money, Credit and Banking, 40(7), 1379-1405.

Belkhir, M., Boubakri, N., \& Grira, J. (2017). Political risk and the cost of capital in the MENA region. Emerging Markets Review, 33, 155-172.

Berger, A., \& Udell, G. (2006). A more complete conceptual framework for SME finance. Journal of Banking and Finance, 30(11), 2945-2966.

Berger, A. N., \& Udell, G. F. (1998). The economics of small business finance: The roles of private equity and debt markets in the financial growth cycle. Journal of Banking \& Finance, 22(6-8), 613-673.

Brei, M., Gadanecz, B., \& Mehrotra, A. (2020). SME lending and banking system stability: Some mechanisms at work. Emerging Markets Review, 43.

Butler, A. W., \& Cornaggia, J. (2011). Does access to external finance improve productivity? Evidence from a nature experiment. Journal of Finance Economics, 99(1), 184-203. https://doi.org/10. 1016/j.fineco.2010.08.009

Canepa, A., \& Stoneman, P. (2007). Financial constraints to innovation in the UK: evidence from CIS2 and CIS3. Oxford Economic Papers, 60(4), 711-730.

Cantwell, J., \& Zhang, Y. (2011). Innovation and location in the multinational firm. International Journal of Technology Management, 54(1), 116-132.

Capozza, C., \& Divella, M. (2019). Human capital and firms' innovation: evidence from emerging economies. Economics of Innovation and New Technology, 28(7), 741-757.

Carter, S., \& Rosa, P. (1998). The financing of male- and female-owned businesses. Entrepreneurship \& Regional Development, 10(3), 225-242.

Chava, S., Oettl, A., Subramanian, A., \& Subramanianm, K. V. (2013). Banking deregulation and innovation. Journal of Financial Economics, 109, 759-774. 
Coad, A., \& Rao, R. (2008). "Innovation and firm growth in high-tech sectors: a quantile regression approach. Research Policy, 37(4), 633-648.

Cornaggia, J., Mao, Y., Tian, X., \& Wolfe, B. (2015). Does banking competition affect innovation? Journal of Financial Economics, 115(1), 189-209.

Correa, P. G., Fernandes, A. M., \& Uregian, C. J. (2010). Technology adoption and the investment climate: firm-level evidence for Eastern Europe and Central Asia. The World Bank Economic Review, 24(1), 121-147.

Corsi, C., \& Prencipe, P. (2018). Foreign ownership and innovation in independent SMEs. A cross-European analysis. Journal of Small Business \& Entrepreneurship, 30(5), 397-430.

Costello, T., \& Prohaska, B. (2013). Innovation. IT Professional, 15(3).

Cowling, M., Liu, W., \& Ledger, A. (2012). Small business financing in the UK before and during the current financial crisis. International Small Business Journal, 30(7), 778-800.

Czarnitzki, D. (2006). "Research and development in small and medium-sized enterprises: the role of financial constraints and public funding. Scottish Journal of Political Economy, 53(3), 335-357.

D’Este, P., Iammarino, S., \& Savona, M. (2012). What hampers innovation? Revealed barriers versus deterring barriers. Research Policy, 41(2), 482-488.

Demirgüç-Kunt, A., \& Maksimovic, V. (1998). Law, finance, and firm growth. The Journal of Finance, 53(6), 2107-2137.

Denicolò, V., \& Zanchettin, P. (2016). Speculative profits, innovation and growth. Economic Enquiry, 55(1), 160-174.

Denis, D. J. (2004). Entrepreneurial finance: an overview of the issues and evidence. Journal of Corporate Finance, 10(2), 301-326.

Djankov, S., McLiesh, C., \& Schleifer, A. (2007). Private credit in 129 countries. Journal of Financial Economics, 84(2), 299-329.

Donbesuur, F., \& Ampong G. O., Owusu-Yirenkyi, D., \& Chu, I., A. (2020). Technological innovation, organizational innovation and international performance of SMEs: The moderating role of domestic institutional environment. Technological Forecasting and Social Change, 161, 120252.

Dornel, A., Ait Ali Slimane, M., \& Mohindra, K. (2020). Improving SME access to trade credit and financing in MENA. The World Bank Group.

EBRD. (2016). What's holding back the private sector in MENA? Lessons from the Entreprise Survey. . European Bank for Reconstruction and Development.

Fernandez, V. (2017). The finance of innovation in Latin America. Journal of International Review of Financial Analysis, 53, 37-47.

Fombang, M. S., \& Adjasi, C. K. (2018). Access to finance and firm innovation. Journa of Financial Economic Policy, 10(1), 73-93.

Fowowe, B. (2017). Access to finance and firm performance: evidence from African countries. Review of Development Finance, 7(1), 6-17.

Freel, M. S. (2007). Are small innovators credit rationed? Small Business Economics, 28(1), 23-35.

Fua, X., Mohnen, P., \& Zanelloc, G. (2018). Innovation and productivity in formal and informal firms in Ghana. Technological Forecasting \& Social Change, 131, 315-325.

García-Pérez-de-Lema, D., Ruiz-Palomo Diéguez-Soto, \& Julio., D. (2021). Analysing the roles of CEO's financial literacy and financial constraints on Spanish SMEs technological innovation. Technology in Society, 64, 101519.

Geretto, E., \& Pauluzzo, R. (2008). The structure of the Chinese banking system and credit access problems for SMEs. Transition Studies review, 15, 558-572.

Girma, S., Görg, H., \& Pisu, M. (2008). Exporting, linkages and productivity spillovers from foreign direct investment. Canadian Journal of Economics/Revue canadienne d'économique, 41(1), 320-340.

Gonzales, E., Hommes, M., \& Mirmulstein, M. L. (2014). MSME Country Indicators, IFC.

Gorodnichenko, Y., \& Schnitzer, M. (2013). Financial constraints and innovation: why poor countries cannot catch up. Journal of European Economic Association, 11(5), 1115-1152.

Graffeo, L. C., \& Silvestri, L. (2006). Relationship between locus of control and health-related variables. Education, 126(3), 593-597.

Guadalupe, M., Kuzmina, O., \& Thomas, C. (2012). Innovation and Foreign Ownershipt. American Economic Review, 102(7), 3594-3627.

Gunjati, S. B., \& Adake, C. V. (2020). Innovation in Indian SMEs and their current viability: A review. Materials Today: Proceedings, 28, 2325-2330.

Hall, B. H. (2002). The financing of research and development. Economic Policy, 18(1), 35-51. 
Hellmann, T., Lindsey, L., \& Puri, M. (2008). Building relationships early: Banks in venture capital . The Review of Financial Studies, 21(2), 513-541.

Higon, D. A. (2012). The impact of ICT on innovation activities: Evidence for UK SMEs. International Small Business Journal, 30(6), 684-699.

Higon, D. A., \& Driffield, N. (2011). Exporting and innovation performance: Analysis of the annual Small Business Survey in the UK. International Small Business Journal, 29(1), 4-24.

Hisrich, R. D. (1992). The need for marketing in entrepreneurship. Journal of Business \& Industrial Marketing, 7(3), 53-57.

IMF. (2019). Enhancing the role of SMEs in the Arab world - some key considerations. PPEA2019040.

Khan, M. S., Breitenecker, R. J., \& Schwarz, E. J. (2014). Entrepreneurial team locus of control: diversity and trust. Management Decision, 52(6), 1057-1081.

King, R. G., \& Levine, R. (1993). Finance and growth: Schumpeter might be right. The Quarterly Journal of Economics, 108(3), 717-737.

La Porta, R., Lopez-de-Silanes, F., Shleifer, A., \& Vichny, R. W. (1997). Legal determinants of external finance. Journal of Finance, 52(3), 1131-1150.

Langan-Fox, J., \& Roth, S. (1995). Achievement motivation and female entrepreneurs. Journal of Occupational and Organizational Psychology, 68(3), 209-218.

Law, S. H., Lee, W. C., \& Singh, N. (2018). Revisiting the finance-innovation nexus: Evidence from a non-linear. Journal of Innvation \& Knowledge, 3, 143-153.

Lee, N., Sameen, H., \& Cowling, M. (2015). Access to finance for innovative SMEs since the financial crisis. Research Policy, 44, 370-380.

Levine, R. (1998). The legal environment, banks, and long-run Eeonomic growth. Journal of Money, Credit and Banking, 30(3), 596-613.

Link, A. N., \& Bozeman, B. (1991). Innovative behaviour in small-sized firms. Small Business Economics, 3(3), 179-184. https://doi.org/10.1007/BF00400023

Love, J. H., Roper, S., \& Zhou, Y. (2016). Experience, age and exporting performance in UK SMEs. International Business Review, 25(4), 806-819.

Malhotra, M., Chen, Y., Criscuolo, A., Fan, Q., Hamel, I. 1., \& Savchenko, Y. (2007). Expanding access to finance : good practices and policies for micro, small, and medium enterprises. World Bank Institute (WBI) Learning Resources Series, 51615.

Mason, C., \& Brown, R. (2013). Creating good public policy to support high-growth firms. Small Business Economics, 40(2), 211-225.

Mazzucato, M. (2013). Financing innovation: creative destruction vs. destructive creation. Industrial and Corporate Change, 22(4), 851-867.

McGuirk, H., Lenihan, H., \& Hart, M. (2015). Measuring the impact of innovative human capital on small firms' propensity to innovate. Research Policy, 44(4), 965-976.

Mina, A., Lahr, H., \& Hughes, A. (2013). The demand and supply of external finance for innovative firms. Industrial and Corporate Change, 22(4), 869-901.

Morris, D. M. (2018). Innovation and productivity among heterogeneous firms. Research Policy, 47(10), 1918-1932.

Nählinderm, J. (2010). Where are all the Female Innovators? Nurses as Innovators in a Public Sector Innovation Project. Journal of Technology Management and Innovation, 5(1), 13-29.

Nightingdale, P., \& Coad, A. (2014). Muppets and gazelles: political and methodological biases in entrepreneurship research. Industrial and Corporate Change, 23(1), 113-143.

Nofsinger, J. R., \& Wang, W. (2011). Determinants of start-up firm external financing worldwide. Journal of Banking \& Finance, 35(9), 2282-2294.

O’Sullivan, M. (2005). Finance and Innovation. In J. Fagerberg, D. Mowery, \& R. Nelson (Eds.), The Oxford Handbook of Innovation. (pp. 240-265). Oxford University Press.

Omar, N. S. (2019). Innovation and economic performance in MENA region. Review of Economics and Political Science, 4(2), 158-175.

Palalic, R., Ramadani, V., \& Dana, L. P. (2017). Entrepreneurship in Bosnia and Herzegovina: focus on gender. European Business Review, 29(4), 476-496.

Paunov, C. (2012). The global crisis and firms' investments in innovation. Research Policy, 41(1), 24-35.

Puri, M., Rocholl, J., \& Steffen, S. (2011). Global retail lending in the aftermath of the US financial crisis: Distinguishing between supply and demand effects. Journal of Financial Economics, 100(3), 556-578. 
Quartey, P., Turkson, E., Abor, J. Y., \& Iddrisu, A. M. (2017). Financing the growth of SMEs in Africa: What are the constraints to SME financing within ECOWAS? Review of Development Finance, 7(1), 18-28.

Rajan, R. G., \& Zingales, L. (1998). Financial dependence and growth. The American Economic Review, $88(3), 559-586$.

Revest, V., \& Sapio, A. (2010). Financing technology-based small firms in Europe: what do we know? Small Business Economics, 39(1), 179-205.

Rothwell, R., \& Gardiner, P. (1989). The strategic management of re-innovation. R\&D Management, 19(2), 147-160.

Rotter, J. B. (1966). Generalized expectancies for internal versus external control of reinforcement. Psychological Monographs, 80(1), 1-28.

Sarto, F., Saggese, S., Viganò, R., \& Mauro, M. (2019). Human capital and innovation: mixing apples and oranges on the board of high-tech firms. Management Decision, 58(5), 897-926.

Sastre, J. F. (2016). Gender diversity and knowledge innovation barriers. International Journal of Entrepreneurship and Small Business, 27(2/3), 193-212.

Scherer, F. M. (1988). Testimony before the Subcommittee on Monopolies and Commercial Law. Committee on the Judiciary, US House of Representatives.

Schneider, C., \& Veugelers, R. (2010). On young highly innovative companies: why they matter and how (not) to policy support them. Industrial and Corporate Change, 19(4), 969-1007.

Schumpeter, J. (1911). The Theory of Economic Development. . Harvard University Press.

Schumpeter, J. (1934). The Theory of Economic Development Cambridge: Harvard University Press.

Stiglitz, J. (2000). The contributions of the economics of the information to Twentieth Century economics. The Quarterly Journal of Economics, 115(4), 1441-1478. https://doi.org/10.1162/003355300555015

Tang, T. T. (2009). Information asymmetry and firms' credit market access: Evidence from Moody's credit rating format refinement. Journal of Financial Economics, 93(2), 325-351.

Ullah, B. (2019). Financial constraints, corruption, and SME growth in transition economies. The Quarterly Review of Economics and Finance, 75, 120-132.

Van Beveren, I., \& Vandenbussche, H. (2010). Product and process innovation and firms' decision to export. Journal of Economic Policy Reform, 13(1), 3-24.

Wang, Y. (2016). What are the biggest obstacles to growth of SMEs in developing countries? - An empirical evidence from an enterprise survey. Borsa Istanbul Review, 16(3), 167-176.

Wellalage, N. H., \& Fernandez, V. (2019). Innovation and SME finance: Evidence from developing countries. International Review of Financial Analysis, 66, 101370.

World Economic Forum (2018) The Global Competitiveness Report 2018, Report.

Wu, N., Bacon, N., \& Hoque, K. (2014). The adoption of high performance work practices in small businesses: The influence of markets, business characteristics and HR expertise. nternational Journal of Human Resource Management, 25, 1149-1169.

Xin, F., Zhang, J., \& Zheng, W. (2017). Does credit market impede innovation? Based on the banking structure analysis. International Review of Economics and Finance, 52, 268-288.

Yano, G., \& Shiraishi, M. (2020). Finance, institutions, and innovation activities in China. Economic Systems, 44, 100835.

Publisher's Note Springer Nature remains neutral with regard to jurisdictional claims in published maps and institutional affiliations. 